\title{
Haematological Variations of Etroplus Suratensis with Respect to Heavy Metal Contamination in Two Distinct Regions of Vembanadu Estuary, South-West Coast of India.
}

\author{
Kannan, V.M. ${ }^{1}$, Renjini, P. ${ }^{1}$, Gopikrishna V.G. ${ }^{1}$, Binsh, M.B. ${ }^{1}$ and Mahesh Mohan ${ }^{1 *}$ \\ ${ }^{1}$ School of Environmental Sciences, Mahatma Gandhi University, Kottayam, Kerala. \\ Email: mahises@gmail.com
}

\begin{abstract}
The anthropogenic release of pollutants, to the aquatic ecosystem, can cause severe damage to the flora and fauna of that ecosystem. Fish is a key unit in many natural food webs, but the effects of organic and inorganic pollutants such as heavy metals, pesticides, fertilizers and suspended solids alter the water quality and may cause many problems to these organisms, such as diseases and structural alterations. Haematological parameters can be considered as a valuable tool to understand the alterations of physiological status of the fish. Vembanad ecosystem is considered as a highly productive zone, and has been divided into two distinct regions by Thannermukkom barriage. The northern part is more prone to pollution from industrial sector. The present study analysed some haematological parameters along with the heavy metal contents and found that elevated concentrations of $\mathrm{Zn}$ and $\mathrm{Pb}$ in fish tissue in Cochin estuary (northern part) than Kumarakom. The concentrations were higher than permissible limit recommended by WHO. The result of the haematological analysis has showed considerable variation between the two sites. A positive statistical correlation was observed between the haematological parameters and heavy metals especially $\mathrm{Cd}$.
\end{abstract}

Keywords: Metal; pollution; fish; tissue

\section{Introduction}

The studies on heavy metal contamination of aquatic system have proved beyond doubt that heavy metals are stable and persistent environmental contaminants since they cannot be degraded or destroyed and tend to accumulate in sediments and soils $[1,2]$. The tremendous increase in the use of heavy metals over the past few decades has resulted in an increased flux of metallic substances in to the aquatic environment $[3,4,5]$. Heavy metals especially $\mathrm{Cd}, \mathrm{Hg}, \mathrm{Pb}$, may exhibit extreme toxicity even at low levels under certain conditions necessitates the regular monitoring of sensitive aquatic environments $[6,7]$.

Estuaries are ecologically and commercially important areas that constitute one of the most productive ecosystems on earth [8]. The biological diversity of the Indian estuarine ecosystem is deteriorating due to various human activities. The continuous discharge of effluents from both domestic and economic sectors caused eutrophication, significant increase in organic concentration and heavy metals in the sediments [9]. The Vembanad estuary is one of the highly productive estuarine ecosystems in peninsular India that acts as a nursery ground for many marine and estuarine species [10]. Several studies were observed tremendous increase in the enrichment of heavy metals in Vembanadu due to industrialization and urbanization [11, 12, 13, 14].

Haematological indices are valuable tool for the evaluation of fish physiological status. Estimation of the toxic effects of the metals can be done by analyzing the basic hematological assays like red blood cells (RBC), white blood cells (WBC), hemoglobin (Hb), mean corpuscular volume (MCV) etc. Studies have shown that blood alteration in fish or damage of hematopoietic tissue organs can be associated with water born pollutants. Blood parameters are considered as patho physiological indicators of the whole body and therefore are important in diagnosing the structural and functional status of fish exposed to toxicants. Exposure to environmental pollutants especially heavy metals causes alterations in the blood characteristics of fishes [15]. The accumulation of heavy metals such as $\mathrm{Zn}, \mathrm{Cd}, \mathrm{Pb}$ and $\mathrm{Cu}$ was high in the different tissues of the selected fishes of Vembanad estuary. Therefore the analysis of 
metals and blood indices is a valuable guide for assessing the condition of fish, as it provides reliable index of their physiological condition and environmental contamination. Little information is available on heavy metal levels and related haematological profile of local fish species in Cochin estuary. Therefore the main aim of this study was to determine the status of metal contamination and haematological changes from normal level of the food fish Etroplus suratensis.

\section{$2 \quad$ Materials and Methods}

\subsection{Study Area}

Vembanadu estuary, one of the three Ramsar sites of Kerala, has an area of 151,250 ha. The Thanneermukkom barrage separates the Vembanad estuary into two pre mentioned regions. In the present study the test animal Etroplus suratensis (Plate 1 \& Table 1) was collected from both Cochin estuary and Kumarakom, the two distinct regions of Vembanad (Fig 1). The Northern Cochin part is the salt water dominant area, and also receives considerable amount of effluents from the industrial sectors. The Southern Kumarakom region carries comparatively less polluted fresh water due to the presence of Thanneermukkom barrage.

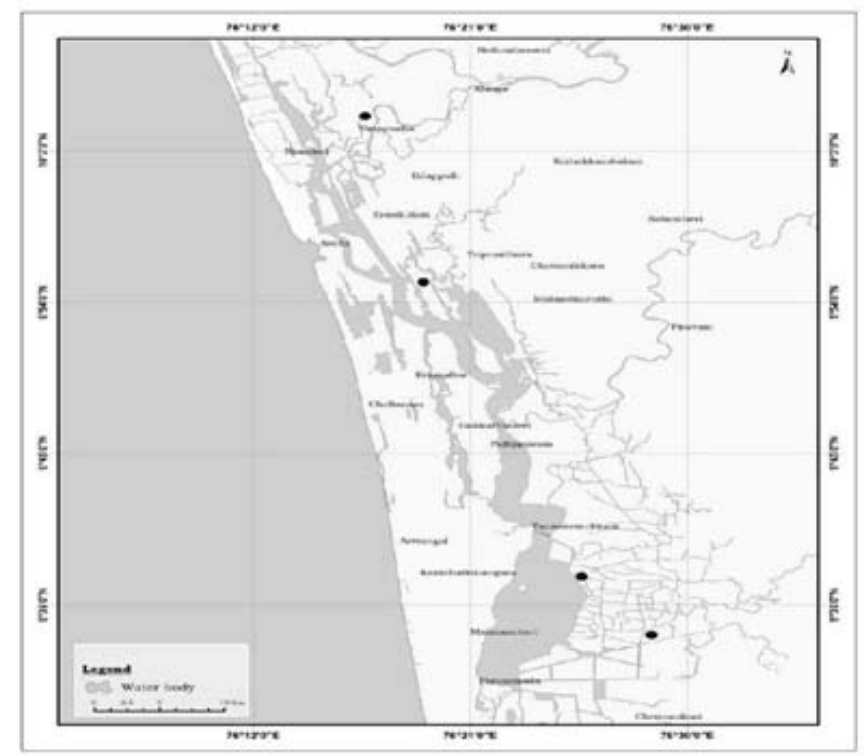

Figure 1. Study area and sampling location

Table 1. Taxonomic characteristics of Etroplus suratensis

\begin{tabular}{l|c|l}
\hline Phylum & $:$ & Vertebrata \\
\hline Subphylum & $:$ & Craniata \\
\hline Super class & $:$ & Gnathostomata \\
\hline Series & $:$ & Pisces \\
\hline Class & $:$ & Teleostei \\
\hline Subclass & $:$ & Actinoptergii \\
\hline Super order & $:$ & Acanthoptergii \\
\hline Order & $:$ & Perciformes \\
\hline Suborder & $:$ & Labroidei \\
\hline Family & $:$ & Cichlidae \\
\hline Genus & $:$ & Etroplus \\
\hline Species & $:$ & Etroplus suratensis \\
\hline
\end{tabular}




\subsection{Sample Collection \& Preparation}

The fish samples were collected from both Kumarakom and Cochin estuary with the help of local fishermen. For this study 10 samples were collected from both regions (Table 2). The blood for haematological analysis was collected from the site itself by heart puncturing using syringe. The blood was then transferred to vials containing ethyl diamine tetra acetic acid (EDTA) as an anticoagulant. After the recording of the morphometric features, fishes were transferred to the ice box and carried to the laboratory. The muscle tissues were dissected and dried in an oven at $50^{\circ} \mathrm{C}$. It was then pulverized and digested with the aid of Microwave Assisted Reaction System (MARS) using suprapur $\mathrm{HNO}_{3}$.

Table 2. List of samples collected from both Kumarakom and Cochin estuary

\begin{tabular}{|c|c|c|c|c|}
\hline & \multicolumn{2}{|c|}{ Kumarakom } & \multicolumn{2}{|c|}{ Cochin estuary } \\
\hline $\mathrm{Sl} \mathrm{No}$ & Samples & Location & Samples & Location \\
\hline 1 & Kvt 1 & \multirow[t]{5}{*}{ Kavanattinkara } & Pan1 & \multirow[t]{5}{*}{ Panangad } \\
\hline 2 & Kvt2 & & Pan2 & \\
\hline 3 & Kvt3 & & Pan3 & \\
\hline 4 & Kvt4 & & Pan4 & \\
\hline 5 & Kvt5 & & Pan5 & \\
\hline 6 & Pch1 & \multirow[t]{5}{*}{ Pallichira } & $\operatorname{Var} 1$ & \multirow[t]{5}{*}{ Varappuzha } \\
\hline 7 & Pch2 & & Var2 & \\
\hline 8 & Pch3 & & Var3 & \\
\hline 9 & Pch4 & & Var4 & \\
\hline 10 & Pch5 & & Var5 & \\
\hline
\end{tabular}

For haematological part standard parameters like Haemoglobin content, Packed Cell Volume, Red Blood Corpuscular, White Blood Corpuscle, Mean Corpuscular Volume (MCV), Mean Corpuscular Haemoglobin (MCH) and Mean Corpuscular Haemoglobin Concentration (MCHC) were adopted. Heavy metal analysis was conducted by using Voltammetric trace metal analyser (797 VA Computerace, Metrohm).

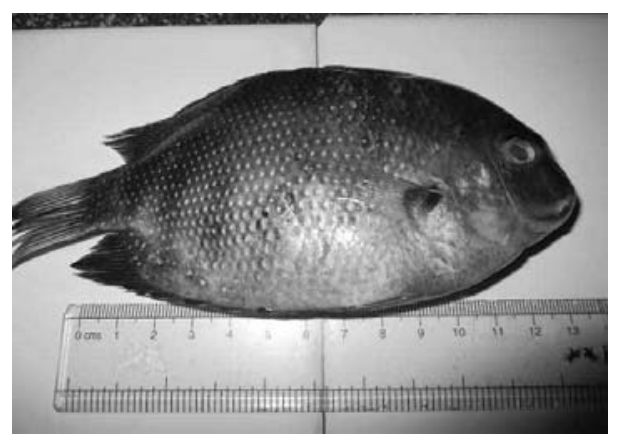

Plate1.Test animal (Etroplus suratensis)

\section{$3 \quad$ Result and Discussion}

The fishes collected from both sites were having approximately equal size and weight (Table 3). Average value of zinc in Kumarakom back water is $18.677 \pm 20.38295 \mathrm{mg} / \mathrm{kg}$ whereas Cochin is $168.078 \pm$ $125.1804 \mathrm{mg} / \mathrm{kg}$ (Table 4). Zn and $\mathrm{Pb}$ were comparatively high in the fishes collected from Cochin compared to Kumarakom back waters. The sediment bound heavy metals may be the reason for the elevated level of metals in Cochin region. Occurrence of $\mathrm{Cd}$ is moderate in fish tissues of Cochin estuary, whereas the least concentration was found in Kumarakom region. Kaladharan et al., 2005 [16] also reported the presence of moderate level of the $\mathrm{Cd}$ in $M$. dobsoni, collected from Cochin estuary, but it 
was less when compared to molluscs and the croaker species. Rajamani et al., 1994 [17] reported high

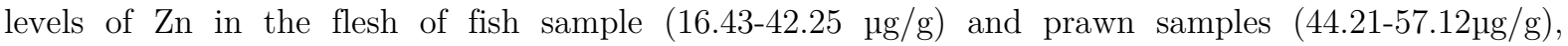
captured from Vembanadu. The present study also proved the elevated level of heavy metal in the order $\mathrm{Zn}>\mathrm{Pb}>\mathrm{Cd}>\mathrm{Cu}$ from both Cochin and Kumarakom estuary.

Table3. List of morphological and heavy metal characteristics of fishes from both regions

\begin{tabular}{l|l|l|l}
\hline Sl no & Parameters & Kumarakom & Cochin estuary \\
\hline 1 & Lenghth $(\mathrm{cm})$ & $16.92 \pm 1.21$ & $17.62 \pm 0.60$ \\
\hline 2 & Weight $(\mathrm{gm})$ & $151.7 \pm 9.54$ & $151.9 \pm 6.09$ \\
\hline 3 & $\mathrm{Zn}(\mathrm{mg} / \mathrm{kg})$ & $18.677 \pm 20.38$ & $168.07 \pm 125.1$ \\
\hline 4 & $\mathrm{Cd}(\mathrm{mg} / \mathrm{kg})$ & $2.347 \pm 2.84$ & $5.457 \pm 6.06$ \\
\hline 5 & $\mathrm{~Pb}(\mathrm{mg} / \mathrm{kg})$ & $3.178 \pm 3.14$ & $19.88 \pm 30.81$ \\
\hline 6 & $\mathrm{Cu}(\mathrm{mg} / \mathrm{kg})$ & $0.36 \pm 0.95$ & $4.275 \pm 30.81$ \\
\hline
\end{tabular}

The heavy metal values obtained for this study were compared with the WHO standards of heavy metals. Among the 20 samples collected from both sites and a few fishes from Cochin estuary showed the accumulation above the permissible limits (Table 4). It may be due to the high inputs of polluted effluents from the urban and industrial sectors. It is very important to monitor heavy metals in the food fish species in Cochin estuary regularly for the safety of fish consumers. The trace metal concentrations analyzed for the samples correlated with the length and weight of the fishes. All the heavy metals except $\mathrm{Cu}$ showed a positive correlation with weight and length, Zn showed significant positive correlation with weight in Cochin estuary.

Table 4. Comparison of heavy metals in biota with WHO standards

\begin{tabular}{|c|c|c|c|c|}
\hline \multirow[b]{2}{*}{ Sl } & & WHO & & \\
\hline & \multirow[b]{2}{*}{ Metals } & \multirow[b]{2}{*}{ standard } & \multirow[b]{2}{*}{ Species } & Present study \\
\hline \multirow{3}{*}{ No } & & & & \multirow[b]{2}{*}{$(\mathrm{mg} / \mathrm{kg})$} \\
\hline & & \multirow[b]{2}{*}{$(\mathrm{mg} / \mathrm{kg})$} & & \\
\hline & & & & \\
\hline 1. & $\mathrm{Zn}$ & 217 & Etroplus suratensis (max.Pan 4) & 453 \\
\hline 2. & $\mathrm{Cd}$ & 9 & Etroplus suratensis. (max. Var 8) & 11.73 \\
\hline 3. & $\mathrm{~Pb}$ & 9 & Etroplus suratensis (max. Pan 3 ) & 96.73 \\
\hline 4. & $\mathrm{Cu}$ & 130 & Etroplus suratensis (max. Pan 2) & 11.5 \\
\hline
\end{tabular}

Table 5. Average blood parameters of Etroplus suratensis from Kumarakom and Cochin estuary

\begin{tabular}{l|l|l|l|l|l|l|l}
\hline Regions & $\begin{array}{l}\text { RBC } \\
\left(10^{6} \mathrm{~mm}^{3)}\right.\end{array}$ & $\begin{array}{l}\text { WBC } \\
\left(10^{3} \mathrm{~mm}^{3)}\right.\end{array}$ & $\begin{array}{l}\text { PCV(packed } \\
\text { cellvolume })\end{array}$ & Hb \% & MCV ( 3$)$ & $\begin{array}{l}\text { MCH } \\
(\mathrm{pg})\end{array}$ & MCHC (\%) \\
\hline Kumarakom & $\mathbf{8 . 7 9 2}$ & $\mathbf{5 3 . 6 6 5}$ & $\mathbf{2 4 . 0 2 6}$ & $\mathbf{8 . 1 9 3}$ & $\mathbf{3 0 . 4 7 4}$ & $\mathbf{9 . 1 0 7}$ & $\mathbf{3 4 . 0 9 7}$ \\
\hline Cochin estuary & $\mathbf{6 . 7 0}$ & $\mathbf{9 4 . 0 4}$ & $\mathbf{2 1 . 0 5}$ & $\mathbf{6 . 8 5}$ & $\mathbf{3 2 . 5 3 6}$ & $\mathbf{1 0 . 5 1 9}$ & $\mathbf{3 2 . 8 9}$ \\
\hline
\end{tabular}

The present investigation has showed visible hematological changes in Etroplus suratensis, collected from both sites (Table 5). The average WBC count of samples from Kumarakom is 53.6 whereas Cochin is 99.4, a significant increase in the WBC counts of Cochin is noted. High level of WBC count indicated damage due to infection of body tissue whereby over production of leucocyte for the immune response. A similar study by Thakur and Pandey in 1990 [18] observed a significant increase in neutrophil and eosinophil, it might be due to immunological reaction to produce more antibodies to cope up with the toxic stress induced by the pulp mill effluent. Increase in neutrophil has also been reported by Lwama et al. in 1976 [19] in coho salmon exposed to industrial effluent. The average erythrocyte count from Kumarakom is 8.79 where as in Cochin is 6.7 , there is significant decrease in the erythrocyte values 
which could be attributed to the destruction of erythrocyte. This may be due to an increased fragility that can lead to shortening the life span of the erythrocyte [20]. In 2014 Sheethu et al. [21] explained that fishes may be anemic due to the stress induced by the heavy metals, which suppress the erythropoiesis ( $\mathrm{RBC}$ forming process). $\mathrm{MCV}, \mathrm{MCH}$ and $\mathrm{MCHC}$ parameters show slight variations between Cochin estuary and Kumarakom. The significant changes in the $\mathrm{MCH}$ of the experimental fishes may be due to the reduction in cellular blood iron resulting in the reduced oxygen carrying capacity of blood and eventually disturb erythropoiesis. In 2008 Kori [22] reported that Zn can affect tissue respiration and heart physiology and proved the effect of $\mathrm{Zn}$ by experimenting with Hetroclarius Sp. The significant decrease in hemoglobin and heamatocrit was observed when the fish exposed to $\mathrm{Zn}$.

Table 6. Correlation between haematological parameters and heavy metal level in Kumarakom backwaters

\begin{tabular}{l|l|l|l|l|l|l|l|l|l|l|l}
\hline & RBC & NBC & PCV & Hb & MCV & MCH & MCHC & Zn & Cd & Pb & $\mathrm{Cu}$ \\
\hline & & & & & & & & & & & \\
\hline RBC & 1 & & & & & & & & & & \\
\hline $\mathrm{WBC}$ & .448 & 1 & & & & & & & & & \\
\hline $\mathrm{PCV}$ & .571 & .077 & 1 & & & & & & & & \\
\hline $\mathrm{Hb}$ & .167 & $.712^{*}$ & .056 & 1 & & & & & & & \\
\hline $\mathrm{MCV}$ & .183 & .427 & .053 & $.797^{* *}$ & 1 & & & & & & \\
\hline $\mathrm{MCH}$ & .223 & .367 & .069 & $.841^{* *}$ & $.912^{* *}$ & 1 & & & & & \\
\hline $\mathrm{MCHC}$ &. .044 & .514 & .090 & $.931^{* *}$ & $.886^{* *}$ & $.968^{* *}$ & 1 & & & & \\
\hline $\mathrm{Zn}$ & .036 & .253 & .003 & .451 & .244 & .343 & .396 & 1 & & & \\
\hline $\mathrm{Cd}$ & .106 & .525 & .366 & $.703^{*}$ & $.663^{*}$ & $.643^{*}$ & $.653^{*}$ & .316 & 1 & & \\
\hline $\mathrm{Pb}$ & .375 & .131 & .192 & .135 & .126 & .351 & .286 & $.744^{*}$ & .026 & 1 & \\
\hline $\mathrm{Cu}$ & .106 & .423 & .133 & .403 & .251 & .300 & .283 & .276 & .318 & .266 & 1 \\
\hline & & & & & & & & & & & \\
\hline
\end{tabular}

Table 7. Correlation between haematological parameters and heavy metal level in Cochin estuary

\begin{tabular}{l|l|l|l|l|l|l|l|l|l|l|l}
\hline & RBC & WBC & PCV & Hb & MCV & MCH & MCHC & Zn & Cd & Pb & Cu \\
\hline & & & & & & & & & & & \\
\hline RBC & 1 & & & & & & & & & & \\
\hline WBC & $-.741^{*}$ & 1 & & & & & & & & & \\
\hline $\mathrm{PCV}$ & -.071 & -.137 & 1 & & & & & & & & \\
\hline $\mathrm{Hb}$ & .509 & -.351 & -.194 & 1 & & & & & & & \\
\hline $\mathrm{MCV}$ & $-.892^{* *}$ & $.640^{*}$ & -.151 & -.317 & 1 & & & & & & \\
\hline $\mathrm{MCH}$ & $-.773^{* *}$ & $.683^{*}$ & -.156 & .109 & $.859^{* *}$ & 1 & & & & & \\
\hline $\mathrm{MCHC}$ & .601 & -.191 & .045 & $.793^{* *}$ & -.619 & -.150 & 1 & & & & \\
\hline $\mathrm{Zn}$ & -.499 & .381 & -.106 & -.397 & $.702^{*}$ & .411 & -.625 & 1 & & & \\
\hline $\mathrm{Cd}$ & -.485 & .313 & .351 & -.523 & .301 & .174 & -.309 & .296 & 1 & & \\
\hline $\mathrm{Pb}$ & $-.682^{*}$ & .631 & -.174 & -.136 & $.808^{* *}$ & $.758^{*}$ & -.439 & $.663^{*}$ & .000 & 1 & \\
\hline $\mathrm{Cu}$ & -.508 & .452 & .240 & -.116 & .327 & .443 & -.119 & -.205 & .054 & .487 & 1 \\
\hline
\end{tabular}

The heamatological parameters of fishes collected from both sites were statistically correlated with heavy metals (Table 6 \& 7). In Kumarakom Zn and $\mathrm{Cd}$ showed a positive correlation with blood parameters, among this $\mathrm{Cd}$ showed significant relation with $\mathrm{Hb}, \mathrm{MCV}, \mathrm{MCH}$ and $\mathrm{MCHC}$. In Cochin estuary $\mathrm{Pb}$ indicated a positive significant correlation with $\mathrm{MCV}$ and $\mathrm{MCH}$. In both sites $\mathrm{Cu}$ showed negative correlation with heamatological indices. 


\section{Conclusion}

Cochin backwater is presently facing serious challenges because of heavy metal contamination. The concentrations of heavy metals in the water as well as sediment at different locations in the backwater system are consistent with the local industrialization levels. Northern part of the estuary is found to be the most polluted compared to other part of the estuary. The present study indicated the selective accumulation of specific metal in edible part of the fish Etroplus suratensis from two different sites of Vembanad Lake, site-1 (Kumarakom backwaters) and site II (Cochin backwaters). Some of the heavy metals like $\mathrm{Zn}$ and $\mathrm{Pb}$ show the elevated concentration in fish tissue in Cochin estuary than Kumarakom, this value is higher than permissible limit recommended by WHO. The result of the haematological analysis shows considerable variation between the two sites. The values of the heavy metals were statistically correlated with the haematological parameters, here a positive statistical correlation was observed between the haematological parameters and heavy metals especially Cd. The detailed relation between the haematology and heavy metals can only be explained with the background of a toxicological study, where the test animal is exposed to the known concentrations of the toxicants and the corresponding fluctuations is recorded. And also more precise environmental protection measures should be taken to control the discharge of heavy metals from anthropogenic sources.

\section{References}

1. U. Forstner and G. T. W. Wittmann, "Metal Pollution in the Aquatic environment," Berlin Heidelberg, New York, Springer, 1979, pp. 532.

2. C. Gisbert, R. Ros, A. D. Haro, D. J. Walker, M. P. Bernal, R. Serrano, and J. Navarro-Avino, "A plant genetically modified that accumulates $\mathrm{Pb}$ is especially promising for phytoremediation," Biochemical and Biophysical Research Communication, Vol. 303, no. 2, pp. 440-445, 2003.

3. A. B. Mukherjee, R. Zevenhoven, P. Bhattacharya, K. S. Sajwan, R. Kikuch, "Mercury flow via coal and coal utilization by-products:a global perspective" Resources Conservation Recycling, Vol. 52, no. 4, pp. 571-591, 2008.

4. S. Wang, D. Zhang, and X. Pan, "Effects of arsenic on growth and photosystem II (PSII) activity of Microcystis aeruginosa,"Ecotoxicology and Environmental Safety, Vol. 84, no. 1, pp. 104-111, 2012.

5. X. X. Yin, L. H. Wang, R. Bai, H. Huang, and G. X. Sun, "Accumulation and transformation of arsenic in the blue-green alga Synechocysis sp. PCC6803," Water Air and Soil Pollution, Vol. 223, no. 3, pp. 1183-1190, 2012.

6. N. Perzadaa, M. Nojok, and C. Lee, "Distribution of heavy metals in the prawns of northern territory, Australia", Marine pollution bulletin, Vol. 24, no. 8, pp. 416-418, 1990.

7. MoEF, "A state-of-the-art report on bioremediation, its applications to contaminated sites in India," Ministry of Environment \& Forests, Paryavaran Bhawan, NewDelhi, 2011.

8. C. Little, "The biology of Soft Shores and estuaries," Oxford University Press, 2000, pp. 16-32.

9. M. Mohan, T. Augustine, K. K. Jayasooryan, M. S. Chandran,and E.V. Ramasamy, "Fractionation of selected metals in the sediments of Cochin estuary and Periyar River, southwest coast of India". The Environmentalist, Vol. 32, no. 4, pp. 383-393, 2012.

10.G. D. Martin, R. George, P. Shaiju, K. R. Muraleedharan, S. M. Nair, and N. Chandramohanakumar, "Toxic metals enrichment in the surficial sediments of a eutrophic tropical estuary (Cochin Backwaters, Southwest Coast of India)", The Scientific World Journal, 2012.

11.K. N. Remani, K. Saraladevi, P. Venugopal and R. V. Unnithan, "Indicator organism of pollution in Cochin backwaters", Mahasagar, Bulletin of National Institute of Oceanography, Vol. 16, no. 2, pp. 199-207, 1983.

12.P. P. Ouseph, "Dissolved and particular trace metals in Cochin estuary", Marine Pollution Bulletin, Vol. 24, no. 4, pp. 181, 1992.

13.C. P. Priju, and A. C. Narayana, "Heavy and Trace Metals in Vembanad Lake Sediments", International Journal of Environmental Research, Vol. 1, no. 4, pp. 280-289, 2007.

14.M. Mohan, M. S. Shylesh Chandran, K. K. Jayasooryan, and E. V. Ramasamy, "Mercury in the sediments of Vembanad Lake, Western coast of India," Environment Monitoring and Assessment, Vol. 186, no. 6, pp. 3321$3336,2014$. 
15.E. V. Ramasamy, A. Toms, C. M. S. Shylesh, K. K. Jayasooryan, and M.Mahesh, "Mercury fractionation in the sediments of Vembanad wetland, west coast of India". Environmental Geochemistry and Health, Vol. 34, no. 5, pp. 575-86, 2012.

16.P. Kaladharan, D. Prema, K. K. Valsala, K. S. Leelabhai, and M. Rajagopalan, "Trends in heavy metal concentrations in sediment, finfishes and shellfishes in inshore waters of Cochin, southwest coast of India", Journal of The Marine Biological Association of India, Vol. 47, no. 1, pp. 1-7, 2005.

17.V. Rajamani Amma V, "The distribution and partition of some of the trace Metals in sediments and waters on the coastal environment", Ph.D Thesis, 1994, Cochin University of Science and Technology, pp. 126.

18.G. K. Thakur and P. K. Pandey, "Poisoning effect on leucocytes of an airbreathing fish, Clarias batrachus (Linn)", Journal of Environmental Biology, Vol. 11, no. 2, pp. 105-110, 1990.

19.G. K. Iwama, G. L. Greer, and P. A. Larkin, "Changes in some hematological characteristics of coho salmon (Oncorhynchus kisutch) in response to acute exposure to dehydroabietic acid (DHAA) at different exercise levels", Journal of the Fisheries Board of Canada, Vol. 33, no. 2, pp. 285-289, 1976.

20.U. Banerjee, A. Dasgupta, J. K. Rout, O.P.Singh, "Effects of lithium therapy on Na+-K+-ATPase activity and lipid peroxidation in bipolar disorder", Progress in Neuro-Psychopharmacology and Biological Psychiatry, Vol. 37, no. 1, pp. 56-61, 2012.

21.R. Sheetu and S. Anupriya, "Effect of Heavy Metal, Zinc and Carbamate Pesticide, Sevin on Haematological Parameters of Fish, Labeo boga, "International Journal of Innovative Research in Science, Engineering and Technology, ISSN: 2319-8753, 2014.

22.S. Kori, Ovie, and O. U. Ewoma, "Sublethal haematological effects of zinc on the freshwater fish, Heteroclarias sp. (Osteichthyes: Clariidae)," African Journal of Biotechnology, Vol. 7, no. 12, pp. 2068-2073, 2008. 